\title{
TEACHERS' BELIEF IN MANAGING CLASSROOM : INDONESIAN CONTEXT
}

\author{
Yasyir Fahmi Mubaraq $^{1}$, Muthia Farida ${ }^{2}$, I Made Wilantara ${ }^{3}$ \\ 1. Program Studi Pendidikan Bahasa Inggris STKIP PGRI \\ Banjarmasin myasyirfahmi@yahoo.com (085249322387) \\ 2. Universitas Lambung Mangkurat thiafarida@gmail.com \\ (085332214053) \\ 3. Program Studi Pendidikan Bahasa Inggris STKIP PGRI \\ Banjarmasin wilantara_kpts@yahoo.com (085348692120)
}

\begin{abstract}
Research in this past 30 years has suggested that teachers' beliefs heavily influence their pedagogical practice. Beliefs also defined as personal theories or concepts. This definition is influenced by the constructivism psychologists who recognize that every individual has his/her own ways of processing the understanding, and beliefs as the results of self-construction. Beliefs may reflect in teachers' teaching. Factors that drive belief include early experiences as learners, experiences in professional coursework, constextual factors, and reflection on teacher's past practices This study is aimed to reveal how teachers' manage their classroom and teachers' belief as well. A descriptive qualitative study is conducted by using observation and questionaire. Teachers from different school and background were choosen in this study.
\end{abstract}

Key words: Teachers' beliefs, Classroom Management, Indonesian Context

\section{A. Background of The Study}

\section{INTRODUCTION}

Based on review of the literature of language teachers' beliefs, a correlation between teachers' beliefs with their classroom practices were identified. Some studies also reveals the lack of attention to this may not only result in a failure to understand current practices in Teaching English to Speakers of Other Languages (TESOL), but also in a failure to understand and develop English-as-a-foreign-language (EFL) teachers from those countries.

Research in this past 30 years has suggested that teachers' beliefs heavily influence their pedagogical practice (for example, Borg 2003; $\mathrm{Ng}$ and Farrell 2003; Mangubhaiet al. 2004), their instructional decisions in the classroom (Tillema, 2000), and acceptance and uptake of new approaches, techniques and activities (Donaghue 2003). As Williams and Burden (1997: 57) note, 'teachers' 
deep-rooted beliefs about how languages are learned will pervade their classroom actions more than a particular methodology they are told to adopt or course book they follow'.

Some of the researchers claimed that early learning experiences have great impact on constructing teachers' beliefs (Richards, et al.,2001; Daisey, 2009). Meanwhile, others also stated that teachers' knowledge and experiences are the source of beliefs (Mellati, et al., 2014). In particular, Williams and Burden (1997: 56) state that beliefs are constructed from the interaction among teachers, students, and classroom context. Borg (2003) also explains that teacher beliefs, namely schooling experiences, professional coursework, classroom practices, and contextual factors. The research has indicated that knowing such factors help teachers as well as educational researchers to investigate why certain beliefs can exist.

Teachers are no longer viewed as robots who merely did what the curricula designers asked to do without thinking (Borg, 2009). Rather, they are now seen as individuals who have thinking manners showing that their personal beliefs constitute their decision-making and actions in the clasroom (Pajares, 1992; William \& Burden, 1997; Donaghue, 2003; Borg, 2009). All in all, there must be underlying reasons behind their decisions and actions that teachers personally believe.

In a different context, Sato and Kleinsasser (2004) investigated the beliefs, practices and interactions of 19 teachers in a Japanese high school English department using interviews, observations and teachers' documents. The study revealed that the teachers' beliefs were closely tied to context, or to the school's (technical) culture - its norms and values. Norms, which teachers described as 'managing students and various task assignments' and 'keeping pace with other teachers', guided not only what they taught, but how they taught (Sato and Kleinsasser 2004, 811). These understandings helped develop teachers' beliefs about teaching 'the same wayfor the common test and to maintain classroom management' (Sato and Kleinsasser 2004).

There are numerous factors that justify the relevance of investigating teacher beliefs. First, it offers insights to teacher education programs in that it enables research to go beyond classroom practice descriptions toward the understanding of teacher action (Johnson, 1992). Second, it can inform curriculum policy in relation to any innovation plausible to particular situations (Burns, 1992). Third, "it can generate grounded alternatives to the 'accepted wisdom' originated from academic traditions and institutions" (Breen, Hird, Milton, Oliver \& Thwaite, 2001, p. 472) because data come directly from classroom work in different contexts. Fourth, it contributes to the notion of reflection on teacher action and helps teachers make their beliefs more explicit at institutional and societal level (Gimenez, 1999). Finally,it helps understand how teachers conceptualize their work (Richards, Gallo \& Renandya, 2001).

Beliefs are divided into two on the basis of whether they are viewed as stable or unstable. When certain beliefs seem to lead them to conduct successful practices, they may tend to hold beliefs continuously (Fives \& Buehl, 2012). These beliefs may be more resistant to change. If teachers experience innovations 
and various conditions which prove helpful and successful, there is prossibility of alternative beliefs appear (Richards, et al., 2001). Such experiences mediate teachers to change their beliefs. To conclude, the stability of beliefs may be depend whether there is hold their prior beliefs.

Teachers, as Borg $(2003,81)$ notes, are 'active, thinking decision-makers who make instructional choices by drawing on complex, practically-oriented, personalized, and context-sensitive networks of knowledge, thoughts, and beliefs'. Understanding language teachers' beliefs cannot be achieved by simple recourse to what they say or do at face value. Rather, a deep understanding is needed of the complex interplay between personal beliefs and context-specific actions as depicted through classroom interaction.

Beliefs also defined as personal theories or concepts. This definition is influenced by the constructivism psychologists who recognize that every individual has his/her own ways of processing the understanding, and beliefs as the results of self-construction (Richards, Gallo, \& Renandya, 2001). In Williams \& Burdern (1997: 53), it is stated that teachers make sense of the world around them, meaning that they process the knowledge from outside particularly regarding the information about their work. In a gradual process, teachers' knowledge becomes concepts in their minds which they accept as the truths if they found out that the knowledge has proven itself in action (Larenas et al., 2015). These personal theories serve as filters to new information and as a guide to teachers' desicion and actions (Donaghue, 2000; Borg, 2001; Five \& Buehl, 2012). In conclusion, teachers' beliefs are similar to teachers' personal theories accepted as the true ones and function as filters to new information and a guide to their practices.

Further, a theory of teacher cognition postulated by Borg (2003) exclusively explains the mechanism of several factors that affect teachers' beliefs as beliefs are within teacher cognition. This theory can be applied to investigate the factors that might affect teachers' beliefs because it represents the relationship among teacher cognition, schooling, professional coursework, contextual factors, and classroom practices with teacher any intervention (innovations, certain contexts, practice) that either mediate or hinder teachers to cognition as the central attention of this theory. The idea of this theory is that teacher cognition which includes beliefs is influenced by teachers' schooling experiences in learning within schooling and professional coursework factors, contextual factors, and classroom practices by either one-way interaction or two-way interaction.

The explanation of each factor is based on Borg (2003). The first factor is schooling also refer to early experiences as learners. They mean extensive experiences as learners which form early cognition and shapes teachers' perception of initial learning. These experiences can be obtained in the early experiences of individual to learn something or from their schools which involve interactions with teachers and peers, the ways their teacher taught, the approach and the methods used, and how they were feeling at that time. It shows that early learning experiences shape the teachers' early beliefs and may continue influencing teachers during their career. 
The second factor is professional coursework which means experiences of teachers in doing any activities and following professional programs/education to improve their professionalism. Such activities are in-service training, attending workshops or seminars, and sharing ideas to colleagues. Professional coursework and teachers' beliefs influence each other showing two-way interactions. It is obviously that professional coursework is the resources of learning for teachers during their career. Thus, the knowledge they get from these resources may impact their existing knowledge. Then their prior beliefs may be modified because of the knowledge modification. At the same time, teachers' beliefs also can give impact to teachers' professional coursework. They may hold a number of beliefs that lead them either to improve their kowledge and skills or not. Finally, it shows that professional coursework and teachers' beliefs are interplay continuously during the teacher's teaching career.

The next is classroom practices that refer to teachers' teaching experiences in the classroom during their teaching career. By taking a look at the arrow, there are also two-way interactions between classroom practices and teachers' beliefs. The existing beliefs that teachers have infuence what teachers are going to do in the classroom. In turn, if teachers reflect on their own classroom experiences and the results of their reflections modify what they think of their teaching, this can be stated that teachers' beliefs are unconsciously and/or consciously affected by their classroom practices.

Lastly, it is contextual factors. The context refers to social, psychological, and environmental realities of school and classroom. In this case, the factors include school policies, curriculum mandates, classroom layout, students, and the availability of resources. It shows that such factors affect both beliefs and classroom practices.Teacher may change their beliefs if they face particular conditions within their own contexts. Then it also may impact their pratices to be changed due to the factors. In short, the factors affect practices either by modifying beliefs or the other way around. Further, the arrows also shows oneway interaction indicating that the existence of contextual factors may not be hindered and changed by teachers. Therefore, these factors may facilitate or hinder teachers to adopt practices that reflect their beliefs. Teachers probably need to adjust their beliefs in order to facilitate their practices if the contexts seem not supportive.

From the explanation, this study decided to focus the potential factors that affect teacher's beliefs. The factors include early experiences as learners, experiences in professional coursework, constextual factors, and reflection on teacher's past practices. It was expected that exploring from these variables enabled this study to gain much information to see the contribution of the factors in influencing the teacher's beliefs.

\section{B. Statement of the Problem}

This study is aimed to answer these following research questions:

1. How do Indonesian teachers manage their classrooms?

2. What are the factors that affect the EFL teachers' belief in managing their classroom? 


\section{Objective of the Study}

The objectives of this study are written as folows:

1. To find out how Indonesian teachers managing their classroom

2. To find out factors that affect the EFL teachers' belief in managing their classroom.

\section{RESEARCH METHODOLOGY}

\section{A. Research Design}

This study uses qualitative approach. This design allows reseachers to provide rich description aimed at understanding phenomenon, a process, or particular point of views from those involved (Ary, Jacobs, Sorensen, \& Razavieh, 2010: 453) that suit the purpose of the study to present a detailed description of the teachers' beliefs in manging classroom. Qualitative research begins with assumptions, a worldview, the possible use of theoretical lens, and the study of research problem inquiring into the meaning individuals or group ascribe to social or human problem (Creswell, 2007: 37).

\section{B. Source of Data}

The data of this study are gained based on purposive random sampling technique. The teachers and school are choosen on the basis of representativeness of the data. There are three teachers from different school as the subject of the study. The data are also obtained from observation and interview to the teachers.

\section{DATA FINDINGS AND DISCUSSIONS}

\section{A. Teachers' Classroom Management}

In order to find out how teachers manage their classroom, the reseachers conduct observation to each teachers. The observation is eager to find out voice changing, focusing, pausing, eye contact, gestures, and movement.

1. Changes in Voice

There are three components of this variation; they are Intonation, level of pitch, and speed. Based on the observation, most of the teachers varied their voice while teaching, especially in intonation and speed. It means there was no teacher spoke flatly and monotonously. However, not all of them varied their level of pitch; pitch here means teacher's voice volume. Teachers usually speak in normal volume, but in particular cases, they can vary it by 
raising their volume of voice. Some observed teachers raised their level of pitch depends on some cases. For example, when they saw that there were some students who did not pay attention (chatting with their seatmates or playing trick to their friends) and/or when they told the students that what they were talking was important. For speed variation, most of the teachers varied it by slowing down their speed. For example, teachers slowed their speed while they were speaking in English and back to normal speed again when they spoke in Bahasa, some teachers even spoke a bit faster when they spoke in Bahasa. For intonation variation, it is including rhyme and stress. Varying intonation means the teachers do not speak flatly and monotonously and without any rhyme and stress. All observed teachers did intonation variation and they had correct rhyme and stress while speaking and explaining the lesson to their students.

Most of the teachers did voice variation only in pre and while activity, but almost none of them did it in post activity. The problem was they lacked of the time. Consequently, while they were in while activity, the bell already rang to indicate the time was up. Based on the interview, all teachers said that they did not have any particular problem for this variation so far.

\section{Focusing}

There are three components of this variation; they are gesture focusing, verbal-cum-gesture focusing, and verbal focusing. Based on the observation, it show that most of the teachers gave focusing in pre activity. They usually gave it when they introduced the lesson to the students. Most of the teachers used verbal focusing that means they focused the lesson by using verbal statement. Only few teachers (it is about one or two teachers) used gesture focusing and verbal-cum-gesture focusing. For example, they wrote something and/or pointed their sentences on the blackboard while they were giving verbal statement, or they just pointed their sentences on the blackboard to make student focus toward that one. Some teachers repeated giving focusing in while activity as well and few teachers did it in post activity.

Based on the interview, the factor of why some teachers did not do focusing on their teaching because they just forgot of it. They directly explained the material without telling to the students what they were going to learn. However, they sometimes did it in particular material, such as when they explained sentence formula in grammar lesson.

\section{Pausing}

Based on the observation, there were few teachers used this variation. Not all of them used this variation to interact students' attention. Most of them would rather reprimand their students directly than become silent. For some teachers who did pausing, usually they suddenly paused in the middle of their sentences in order to get their students' attention. For example, the students became noisy while teacher was giving explanation. From the interview data, some teachers who did 
not do this variation told that this kind of variation did not work to their students. Therefore, they usually used verbal reprimand.

\section{Eye Contact}

There are three components of this variation: looking at whole class, looking at students' eyes, and looking at one straight point. The data show that most teachers varied their eye contacts. However, they would rather look at whole class while teaching. Teachers usually looked at students' eyes when they asked the students for questions, reprimanded the students to pay attention, or listened to the students who asked questions. Generally, the teachers had varied their eye contacts. However, few teachers still mostly looked at one straight point while they were explaining the lesson.

\section{Gestures}

Almost all of observed teachers always used gesture while they are speaking. Most of them used gesture to help them to become more communicative and interactive. Some teachers also used gesture instead of using verbal reprimand to get students' attention. For example, they knocked the blackboard or table when the students became noisy. They also used gesture to point a student to do something, such as to write something on the blackboard, to answer the question, etc.

\section{Movement}

There are three components of this variation: moving to the whiteboard for writing something, moving to pupils in classroom to guide them when they are doing the given assignment, and moving to the pupils to listen to them.

Most teachers did movement variation in while activity. In pre activity, they usually preferred standing in front of the class to moving to approach the students. Only some teachers did movement variation in pre activity. They usually moved to write something on the blackboard, approached the students to listen to them while they were giving brainstorming to introduce a new topic, or just reviewed the previous lesson.

In while activity, their movements were varied. It means they changed their movement by approaching the students to guide them while they were doing the task, moving to students to listen to their questions, or moving to the blackboard to write something. Although some teachers had varied their movements in while activity, still there were few teachers preferred sitting on their chairs than moving around when their students did the tasks.

In post activity, almost all teacher were run out their time in while activity so that they usually missed the time to end the class. This is the factor of why most teachers did not do some variations in post activity, but still there were few teachers could manage their time. 


\section{B. Variation In Using Media}

Based on the observation, it show that some teachers did not use teaching aids or media while they were teaching their students. Most of them just used the book in their teaching processes. Only few teachers did use the media, and it was various enough between the teachers. There was a teacher who used the things in the classroom or students' things as media. For example, cell phone, stationery, eraser, etc. to introduce the lesson in pre activity; there was also a teacher who used word cards to introduce the lesson in pre activity and as a game in post activity; two teachers used LCD projector as the media (one teacher used video and another one used pictures and online article). The other media used by teachers were a newspaper, a photo, and teacher's voice. From the observation data, the media that were used by teachers can be classified as follow:

- Visual media: pictures and photos.

- Aural media: teacher voice

- Audio-visual: video

- Tactile media: word cards, real things (such as stationery, eraser, students' cell phones) and newspaper.

The time of using media was also various between the teachers. Some of them used media to introduce the lesson in pre activity, some of them used it for explanation and exercise in while activity, and one teacher used it as a game in post activity.

Based on the interview, the reason of why some teachers did not use media because they lacked of media, they did not have time to prepare the media, and some of them said that some materials can be taught and still understandable without using media (for example, when they were teaching reading). Two of the teachers who used their voice instead of using tape recording stated that the school do not have language laboratory so that they had to read the script. Actually, the school has a tape player, but they said that it is quite heavy to carry on. Therefore, they would rather use their voice than use recording. All teachers said that sometimes they still used media in their teaching; it was not quite often however.

\section{Variation Interaction}

Based on the data from the observation, the most common interaction type used by teachers was T-S-T interaction (teachers asked students and students gave their feedback). Almost all teachers used this interaction type both in pre and while activity. However, some of teachers still used traditional type, which means that the teachers still became the center of activity; usually teachers used this kind of interaction in pre activity. Only some teachers implemented T-S-S interaction and it was especially for speaking class when they asked the students to make a dialogue in pair.

Based on the interview, teachers actually often used T-S-S in their class by dividing the students into some groups to do the tasks, it was not quite often however because sometimes the students counted on some 
members of the group to do it. Therefore, teachers usually preferred individual work to group work. About T-S, S-S, S-T and around interaction, all teachers almost never did it. They said that it is less effective because they considered the time and the number of the students in the class were not possible to make that interaction.

\section{Factors affecting teachers' belief}

To answer the second question, the factors affecting the teachers' beliefs were explored through the interview. These factors were classified into four: early learning experiences, professional coursework, contextual factors, and reflection on classroom practices.

First of all, the teacher's early EFL learning experiences were from their experiences when studying in the English Department and at the beginning of their career as teachers. Based on the interview, two teachers are from private college and one of them from state university. All of them claimed that they already got the knowledge for managing classroom. They also said that most of their knowledges were applied in their teaching.

Secondly, the result of interview showed that the knowledge they got from professional coursework has affected their teaching. they stated that they usually attended national and international conferences/seminars. From such activities, they could learn from and share ideas with other teachers and update themself with current ELT development issues.

Thirdly, the exploration of the contextual factors faced by the teacher showed whether the school and classroom contexts influenced their beliefs. Related to the characteristics of their students, they claimed that they came from different academic and socio-cultural backgrounds. The next point was about the classroom situation and facilities. One of teacher said that he had to modify the media with a traditional one since school did not provide LCD.

Fourthly, it was related to the reflection on the past classroom practices. First, the teachers were asked about what contraints that they usually encountered during their practices so far. They answered that taking care of all the students with their different proficiency was not easy. What they could do was optimizing their feedback orally and writtenly.

All in all, the factors that affect the teacher's beliefs were early learning experiences, reflection on classroom practices, professional coursework, and students' proficiency.

\section{CONCLUSION \& SUGGESTIONS}

\section{A. Conclusion}

Almost all the teachers beliefs were reflected in their practices. Experiences, knowledge about teaching, and intention to perform the intended actions had by the teacher played determinant factors mediating the 
consistency between beliefs and practices. However, the school condition is also drive the act of the teachers.

Finally, the factors that affected the teacher's beliefs were learning experiences, reflection on classroom practices, professional coursework, and the students' proficiency.

\section{B. Suggestions}

A number of suggestions are offered to the EFL teachers and the future researchers. They are as follows and practices can be used as a selfreflection for the participant teacher as well.

The teacher's beliefs and practices which were in line with pedagocal theories can be the references for other EFL in constructing their own teaching. EFL teachers should also make their teaching flexible as well as to mix-and-match their instructional preferences to be adaptive with the dynamic situation of the classroom and school. Finally, EFL teachers should always be up-to-date and open to new information regarding the latest educational issues by attending conferences and reading latest research articles so that the knowledge underlying their beliefs can lead them to more effective teaching. It is also important that the EFL teachers should empower themselves with the technology literacy so that they can maximize the use of ICT in their practices.

Future researchers who are willing to investigate teacher' beliefs and practices in teaching writing are recommended to explore other settings of research, such as in other writing courses or in other levels of education. Thus, the comparison among teachers' beliefs in different settings can be obtained. Meanwhile, future researchers should expand the exploration regarding other factors since this study revealed that culture-related belief also contributed to the EFL teacher's beliefs. Moreover, this study also showed that the teacher's intention which indicated her self-determination in teaching contributed to her beliefs and practices.

\section{REFERENCES}

Ary, D., Jacobs, L.C., Sorensen, C., \& Razavieh, A. 2010. Introduction to Research in Education ( ${ }^{\text {th }}$ Edition). Belmonth, CA: Wadsworth.

Creswell, John W. (2007). Qualitative Inquiry \& Research Design. London: Sage Publication

Breen, M.P., B. Hird, M. Milton, R. Oliver, and A. Thwaite. 2001. Making sense of language teaching: Teachers' principles and classroom practices. Applied Linguistics 22, no. 4: 470-501.

Borg, S. 2003. Teacher cognition in language teaching: A review of research on what

language teachers think, know, believe, and do. Language Teaching 36: 81-109. 
Burns, A., and J. Knox. 2005. Realisation(s): Systemic-functional linguistics and the language

classroom. In Applied linguistics and language teacher education, ed. N. Bartels, 235-59. New York: Springer.

Donaghue, H. 2003. An instrument to elicit teachers' beliefs and assumptions. ELT Journal 57, no. 4: 344-51.

Farrell, T.S.C., and S.T.K. Kun. 2008. Language policy, language teachers' beliefs, and classroom practices. Applied Linguistics 29, no. 3: 381-403.

Fives, H. \& Buehl, M.M. 2012. Spring Cleaning for the "Messy" Construct of Teachers' Beliefs: What Are They? Which Have Been Examined? What Can They Tell Us? In K.R. Harris, S. Graham, \& T. Urdan. APA Educational Psychology Handbook. (Online), (http://www.montclair.edu/profilepages/media/1391/user/Fives_\%26_Bue hl_2012.pdf), retrieved on January 8, 2016.

Larenas, C.D., Hernandez, P.A., \& Navarette, M.O. 2015. A Case Study on EFL Teachers' Beliefs About the Teaching and Learning of English in Public Education. Porta Linguarium, 23(-): 171-186. (Online), (http://www.ugr.es/ portalin/articulos/PL_numero23/11\%20\%20Claudio \%20Diaz.pdf), retrieved on January 8, 2016.

Mangubhai, F., P. Marland, A. Dashwood, and J.-B. Son. 2004. Teaching a foreign language: One teacher's practical theory. Teaching and Teacher Education 20, no. 3: 291-311.

Mellati, M., Khademi, M., \& Shirzadeh, A. 2015. The Relationships among Sources of Teacher Pedagogical Beliefs, Teaching Experiences, and Student Outcomes. International Journal of Applied Linguistics and English Literature, $\quad 4(2): \quad 177-184 . \quad$ (Online), (http://www.journals.aiac.org.au/index.php/IJALEL/article/view/1222/118 0), retrieved on October 5, 2014.

Ng, E.K.J., and T.S.C. Farrell. 2003. Do teachers' beliefs of grammar teaching match theirclassroom practices? A Singapore case study. In English in Singapore: research on grammar,ed. D. Deterding, A. Brown, and E. L. Brown, 128-37. Singapore: McGraw Hill.

Pajares, M.F. 1992. Teachers' Beliefs and Educational Research: Clearing up a Messy Construct. Review of Educational Research, 62(3): 307-332.

Richards, J. 1996. Teachers' maxims in language teaching. TESOL Quarterly 30, no. 2: 281-96. 
Richards, J.S. 2001. Curriculum Development in Language Teaching. Cambridge: Cambridge University Press.

Richards, J.C., Gallo, P. B., \& Renandya, W. A. (2001). Exploring Teachers' Beliefs and the Processes of Change. PAC Journal, 1 (1): 41-58. (Online), (http://www.pac-teach.org/jrnl-v1/pacj1-E.pdf), retrieved on February 18, 2015.

Sato, K., and R.C. Kleinsasser. 2004. Beliefs, practices, and interactions of teachers in a Japanesehigh school English department. Teaching and Teacher Education 20: 797-816.

Tillema, H.H. 2000. Belief change towards self-directed learning in student teachers: Immersion in practice or reflection on action. Teaching and Teacher Education 16: 575-91.

Williams, M., and R. Burden. 1997. Psychology for language teachers.

Cambridge: Cambridge University Press 